\title{
CONSILIUM
}

Berkala Kajian Konseling Dan Ilmu Keagamaan

Avalaible at http://jurnal.uinsu.ac.id/index.php/consilium

ISSN : 2338-0608 (Print) | ISSN : 2654-878X (Online)

\section{Hubungan Antara Dukungan Keluarga dan Peer Group Support Terhadap Pemilihan Sekolah Menengah Atas dan Sederajat pada Peserta Didik SMP}

\author{
Aswidi Wijaya Cipta ${ }^{1 *}$, Ramtia Darma Putri², Asriany ${ }^{1}$ \\ 1STKIP Muhammadiyah Palopo, Sulawesi Selatan, Indonesia \\ 2Universitas PGRI Palembang, Palembang, Indonesia. \\ *Korespondensi: aswidiwijayacipta@gmail.com
}

\begin{abstract}
Masa remaja merupakan masa transisi perkembangan antara masa kanak-kanak dan masa dewasa yang mengandung perubahan besar baik fisik, kognitif, dan psikososial yang saling bertautan dalam semua ranah perkembangan. Sebagai remaja, peserta didik pada jenjang sekolah menengah pertama (SMP) sudah sewajarnya memiliki berbagai macam keinginan dan cita-cita setelah lulus. Mereka dihadapkan pada berbagai alternatif pilihan yang perlu dilakukan untuk mengantisipasi program yang harus ditempuh selanjutnya setelah menyelesaikan pendidikan. Tujuan penelitian ini adalah untuk mengetahui hubungan antara dukungan keluarga dan peer group support dengan pemilihan sekolah menengah atas sederajatpada peserta didik SMP Negeri di kabupaten Luwu. Desain penelitian yang digunakan dalam penelitian ini adalah pendekatan kuantitatif. Instrumen (alat ukur) dalam penelitian ini adalah kuesioner yang merupakan hasil pengembangan dari teori dan disusun pada operasionalisasi konsep. Pertanyaan dalam kuesioner menggunakan skala likert. Berdasarkan tujuannya, penelitian ini adalah penelitian korelasional. Sampel sebanyak 60 orang yang akan diambil dari 6 (enam) sekolah menengah pertama negeri. Data tersebut diolah dan dianalisa sesuai dengan yang diperlukan. Prinsip dasarnya adalah menggunakan analisis stastistik karena data yang dapatkan berjumlah besar dan dapat diklasifikasikan dalam berbagai kategori yang ditentukan. Analisis statistik yang digunakan adalah statistik inferensial karena tujuan dari penelitian ini adalah melihat apakah ada hubungan korelasi antar variabel. Oleh karena itu dilakukan uji hipotesis dan uji korelasi antar variabel. Tingkat signifikansi yang digunakan adalah $5 \%$.
\end{abstract}

Kata Kunci: Dukungan Keluarga, Peer Group Support, Pemilihan Sekolah

\section{PENDAHULUAN}

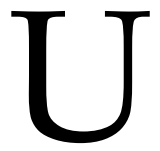

ndang-Undang Republik Indonesia Nomor 20 Tahun 2003 Tentang Sistem Pendidikan Nasional pasal 3 menjelaskan, " pendidikan nasional berfungsi mengembangkan kemampuan dan membentuk watak serta 
peradaban bangsa yang bermartabat dalam rangka mencerdaskan kehidupan bangsa, bertujuan untuk berkembangnya potensi peserta didik agar menjadi manusia yang beriman dan bertakwa kepada Tuhan Yang Maha Esa, berakhlak mulia, sehat, berilmu, cakap, kreatif, mandiri, dan menjadi warga negara yang demokratis serta bertanggung jawab". Salah satu lembaga pendidikan formal adalah sekolah sangat berperan untuk mewujudkan tujuan tersebut.

Masa remaja merupakan masa transisi perkembangan antara masa kanak-kanak dan masa dewasa yang mengandung perubahan besar baik fisik, kognitif, dan psikososial yang saling bertautan dalam semua ranah perkembangan (Ghozaly, 2011). Sebagai remaja, peserta didik pada jenjang sekolah menengah pertama (SMP) sudah sewajarnya memiliki berbagai macam keinginan dan cita-cita setelah lulus. Mereka dihadapkan pada berbagai alternatif pilihan yang perlu dilakukan untuk mengantisipasi program yang harus ditempuh selanjutnya setelah menyelesaikan pendidikan. Dalam kondisi yang demikian ini kualitas kesiapan mental dan kemampuan siswa sangat berperan dalam proses pengambilan keputusan, artinya pihak luar hanya sebatas memberikan bimbingan dan pengarahan, sedangkan pengambilan keputusan sepenuhnya berada pada siswa itu sendiri setelah memperhatikan dan mempertimbangkan masukan dari pihak lain (Dharmayanti, 2014)

Menjelang kelulusan, peserta didik biasanya dihadapkan berbagai macam pilihan setelah lulus. Pilihan tersebut antara lain melanjutkan ke jenjang yang lebih tinggi (SMA, SMK, atau MA), melanjutkan sekolah sambil mengikuti kursus baik akademik maupun keterampilan, tidak melanjutkan tetapi mengikuti khursus-khursus keterampilan, atau mencari pekerjaan yang memang diperuntukkan bagi lulusan SMP dan berbagai pilihan lainnya. Menentukan dan memilih salah satu program lanjutan sekolah lulusan SMP pada dasarnya adalah memilih suatu jalan atau media untuk mendapatkan suatu keahlian tertentu yang nantinya digunakan untuk mendapatkan pekerjaan tertentu (Dharmayanti, 2014). Diantara kelompok yang memberikan kontribusi terhadap pemilihan sekolah lanjutan pada peserta didik adalah dukungan orang tua dan peer group support, sebagai tempat berinteraksi setiap hari.

Dukungan orang tua dapat dilihat dari proses interaksi yang dikembangkan oleh orang tua dengan indikator berupa perawatan, kehangatan, persetujuan, dan berbagai perasaan positif orang tua terhadap anak (Lestari, 2012). Beberapa bentuk dukungan sosial orang tua yaitu berupa dukungan 
emosional berupa penghargaan, perhatian, cinta, kepercayaan dan kesediaan untuk mendengarkan. Kemudian dukungan instrumental yaitu berupa bantuan uang, kesempatan, dan modifikasi lingkungan. Selain itu juga ada dukungan informatif yaitu berupa nasehat, arahan langsung, dan informasi. Secara fungsional, keluarga memiliki dua fungsi yang esensial keluarga yakni pertama keluarga sebagai tempat sosialisasi yang utama bagi anak-anak dan tempat mereka dilahirkan dan kedua tempat stabilitas kepribadian remaja atau orang dewasa. Artinya sebuah sistem dalam keluarga harus melengkapi, memelihara, dan memperbaiki baik motivasi individual maupun pola kultural yang menciptakan dan menopang inovasi (Ritzer \& Goodman, 2012). Pola komunikasi membentuk pemahaman dan kepribadian anak sebagai hasil dari proses pendidikan. Pola komunikasi keluarga yang dijelaskan oleh McLeon dan Chafee terdiri dari pola laissez-faire, protektif, pluralistik dan konsensual (Turner B, 2006).

Sebagian besar waktu remaja dihabiskan di sekolah atau tempat lain di mana remaja memaksimalkan pencapaiannya terhadap prestasi dan juga sebagai bagian dari proses identifikasi sosialnya, sehingga ia dapat menentukan identitas sosialnya sendiri. Di sisi lain, mereka juga mengetahui kebutuhan mereka yang sangat besar atas hubungan dengan teman sebaya mereka, terutama teman terdekat atau peer group mereka. Hubungan ini akan menjadi indikator penerimaan dari teman sebaya yang nantinya akan berdampak pada kepercayaan diri individu dan kemampuannya untuk mengembangkan diri sehingga dapat diterima di lingkungannya terutama dalam bidang akademik (Chairunnissa, 2010). Adanya dukungan dari teman sebaya inilah juga akan ikut menentukan pilihan peserta didik untuk melanjutkan studi pada jenjang pendidikan yang lebih tinggi. Apalagi, umur peserta didik pada tingkat SMP masih labil secara emosi, sehingga pilihannya terkadang berubah seiring dengan interaksinya dengan teman sebayanya. Pada remaja yang bersekolah, maka bisa dikatakan hampir lebih 8 jam dalam sehari mereka habiskan waktu di sekolah bersama teman sebaya dan guru (Budiarti, 2016). Oleh karena itu, faktor-faktor yang berangkat dari relasi sosial di dunia nyata ini kemudian menjadi penting untuk dilihat lebih lanjut.

Berdasarkan uraian di atas, permasalahan penting yang akan diteliti adalah hubungan antara dukungan keluarga dan peer group support terhadap pemilihan Sekolah Menengah Atas dan Sederajat pada Peserta Didik SMP di Kabupaten Luwu. Urgensi dan kontribusi penelitian ini adalah sebagai kajian 
ilmiah dan praktis agar peserta didik dapat melanjutkan karir studinya pada jenjang lanjutan secara merdeka dan bertanggungjawab.

\section{METODE PENELITIAN}

Pendekatan penelitian ini menggunakan pendekatan kuantitatif. Instrumen (alat ukur) dalam penelitian ini adalah kuesioner yang merupakan hasil pengembangan dari teori dan disusun pada operasionalisasi konsep. Pertanyaan dalam kuesioner menggunakan skala likert. Berdasarkan tujuannya, penelitian ini adalah penelitian korelasional. Populasi penelitian ini adalah peserta didik pada Sekolah Menengah Pertama di kabupaten Luwu. Teknik sampling yang dipakai adalah teknik sampling non-probabilitas, dengan pertimbangan seperti penghematan biaya, waktu, kemampuan dan tenaga. Sampel yang ditetapkan sebanyak 60 orang yang akan diambil dari 6 (enam) sekolah menengah pertama negeri.

Penjelasan untuk kriteria inklusi dan ekslusi diberikan oleh peneliti dimana petunjuk pengisian kuisioner serta surat pengantar responden dan surat pernyataan bersedia menjadi responden disertakan dalam angket penelitian. Data tersebut diolah dan dianalisa sesuai dengan yang diperlukan. Prinsip dasarnya adalah menggunakan analisis stastistik karena data yang dapatkan berjumlah besar dan dapat diklasifikasikan dalam berbagai kategori yang ditentukan. Analisa statistik yang digunakan adalah statistik inferensia karena tujuan dari penelitian ini adalah melihat apakah ada hubungan korelasi antar variabel. Oleh karena itu dilakukan uji hipotesis dan uji korelasi antar variabel. Setelah didapatkan hasilnya, lalu dikaitkan dengan analisis teori yang dipergunakan. Tingkat signifikansi yang digunakan adalah $5 \%$.

Secara ringkas, pentahapan penelitian ini adalah sebagai berikut: 


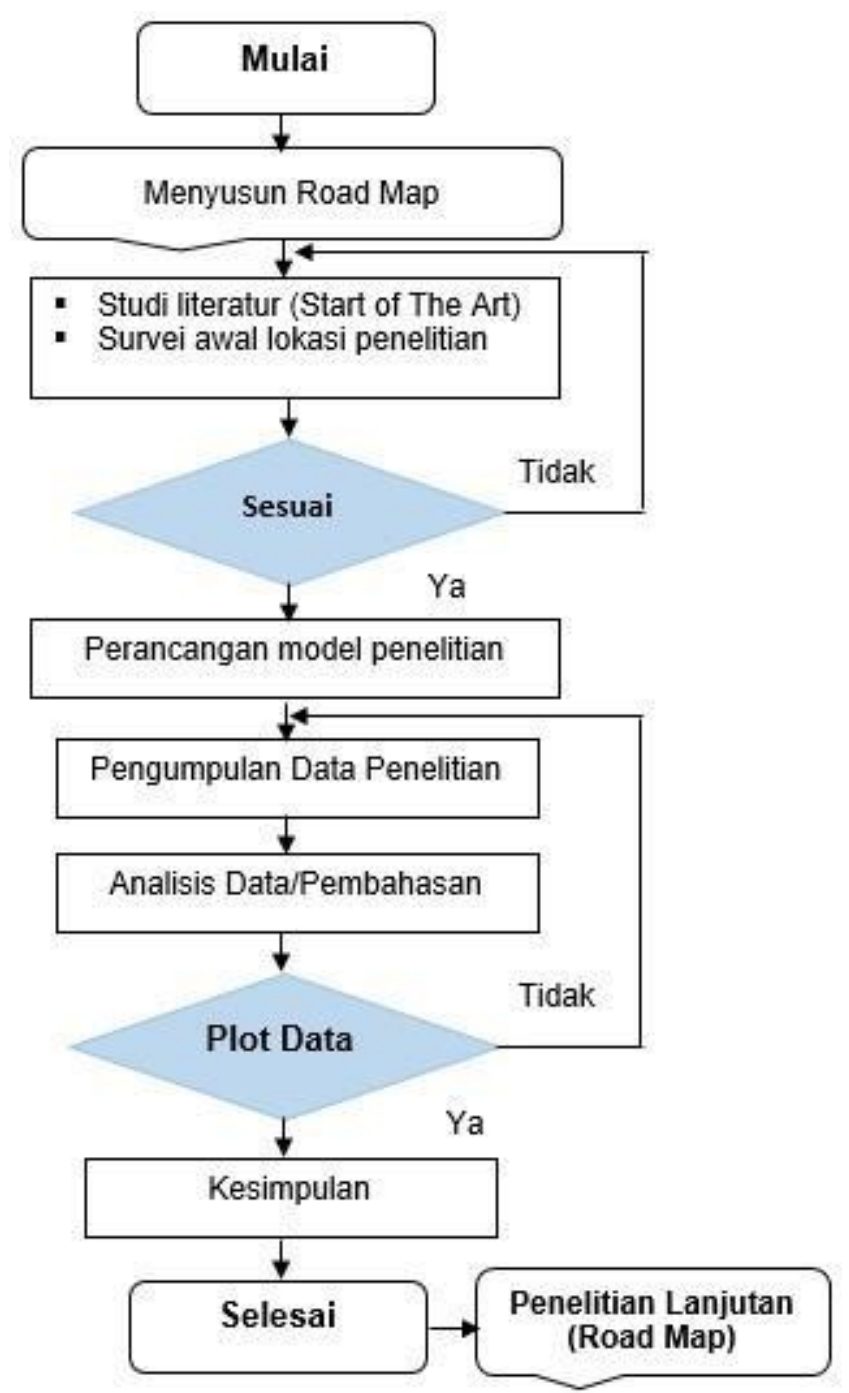

\section{Gambar 1. Diagram Alir Pentahapan Penelitian}

Penelitian ini melibatkan 3 (tiga) personil) yakni ketua pengusul (Aswidy Wijaya Cipta) yang bertugas; (1) penanggungjawab; (2) memberi arahan kepada tim; (3) memantau setiap tahapan dalam penelitian; (4) mempersiapkan segala sesuatu yang dibutuhkan dalam penelitian; dan (5) membuat laporan hasil penelitian. Sedangkan anggota peneliti 1/dosen Universitas PGRI Palembang (Ramtia Darma Putri) bertugas: (1) membantu ketua tim memberi arahan kepada tim; (2) membantu ketua tim mempersiapkan tahapan penelitian; (3) membantu ketua tim memantau setiap tahapan penelitian; dan (4) membantu ketua tim menyusun laporan penelitian. Anggota tim non-dosen (Asriany) bertugas: membantu tim dalam mendokumentasikan administrasi penelitian, keuangan, penyebaran kuisioner, dan analisis data. 


\section{HASIL PENELITIAN DAN PEMBAHASAN \\ Despripsi Penelitian}

Pada bab ini akan dijelaskan mengenai temuan dan analisis data yang dibagi menjadi beberapa sub bagian, yaitu anasisis deskripsi dan analisis bivariat Pada bagian ini akan dijelaskan mengenai paparan atas temuan data serta analisis data dan hubungan antar variabel. Penelitian ini dilakukan dengan mengambil responden sebesar 60 orang.

\section{Analisis Univariat \\ Dukungan Keluarga}

Pada bagian ini akan dipaparkan dan dijelaskan temuan data mengenai dukungan keluarga, dengan item pertanyaan sebagai berikut:

Tabel 1. Hasil Skoring Item Dukungan Keluarga

\begin{tabular}{|c|l|c|c|c|c|c|c|}
\hline \multirow{2}{*}{ No } & \multicolumn{1}{|c|}{ Pernyataan } & \multicolumn{3}{|c|}{ Hasil Skoring (\%) } & Total \\
\cline { 3 - 7 } 1 & & SS & S & CS & TS & STS & \\
\hline & $\begin{array}{l}\text { Orangtua cenderung memaksakan } \\
\text { pilihan karier/pekerjaannya kepada } \\
\text { saya }\end{array}$ & 0 & 16,7 & 36,7 & 46,6 & 0 & 100,0 \\
\hline 2 & $\begin{array}{l}\text { Orangtua mudah diajak bertukar } \\
\text { pikiran tentang kelanjutan studi saya }\end{array}$ & 0,0 & 0,0 & 56,7 & 38,8 & 5,0 & 100,0 \\
\hline 3 & $\begin{array}{l}\text { Orangtua memberi masukan } \\
\text { mengenai karier/pekerjaan saya }\end{array}$ & 0,0 & 40,0 & 30,0 & 28,3 & 1,7 & 100,0 \\
\hline 4 & $\begin{array}{l}\text { Orangtua saya mengingatkan baik- } \\
\text { buruknya dalam pengambilan suatu } \\
\text { keputusan }\end{array}$ & 0,0 & 23,4 & 35,0 & 38,3 & 3,3 & 100,0 \\
\hline 5 & $\begin{array}{l}\text { Orangtua memberikan dorongan } \\
\text { bahwa saya akan mendapatkan } \\
\text { sesuatu yang terbaik }\end{array}$ & 0,0 & 13,4 & 50 & 38,3 & 3,3 & 100,0 \\
\hline 6 & $\begin{array}{l}\text { Orangtua memberi kebebasan } \\
\text { untuk beraktivitas dalam } \\
\text { mengembangkan bakat/minat saya }\end{array}$ & 1,7 & 18,3 & 41,7 & 26,7 & 11,7 & 100,0 \\
\hline 7 & $\begin{array}{l}\text { Orangtua menyarankan untuk } \\
\text { mencari informasi lebih banyak } \\
\text { tentang sekolah lanjutan yang akan } \\
\text { saya pilih }\end{array}$ & 0,0 & 20,0 & 35,0 & 38,3 & 6,7 & 100,0 \\
\hline 8 & $\begin{array}{l}\text { Orangtua saya mengerahkan } \\
\text { segala kemampuannya demi } \\
\text { perkembangan anaknya }\end{array}$ & 1,7 & 15,0 & 43,3 & 31,7 & 8,3 & 100,0 \\
\hline
\end{tabular}




\begin{tabular}{|c|l|c|c|c|c|c|c|}
\hline 9 & $\begin{array}{l}\text { Orangtua tidak membatasi kegiatan } \\
\text { saya selama hal itu menunjang } \\
\text { karier/pekerjaan saya nantinya }\end{array}$ & 0,0 & 23,3 & 33,3 & 35,0 & 8,4 & 100,0 \\
\hline 10 & $\begin{array}{l}\text { Orangtua bersedia mengeluarkan } \\
\text { biaya jika berkaitan dengan } \\
\text { pendidikan saya }\end{array}$ & 0,0 & 23,3 & 43,3 & 28,3 & 5,1 & 100,0 \\
\hline
\end{tabular}

Berdasarkan tabel 1 hasil skoring secara keseluruhan pada item dukungan keluarga, tabel diatas menunjukkan bahwa sebagian besar keluarga cukup setuju dan sejutu dalam memberikan dukungan terhadap peserta didik SMP di Kabupaten Luwu. Berikut hasil scoring, disajikan dalam bentuk diagram batang:

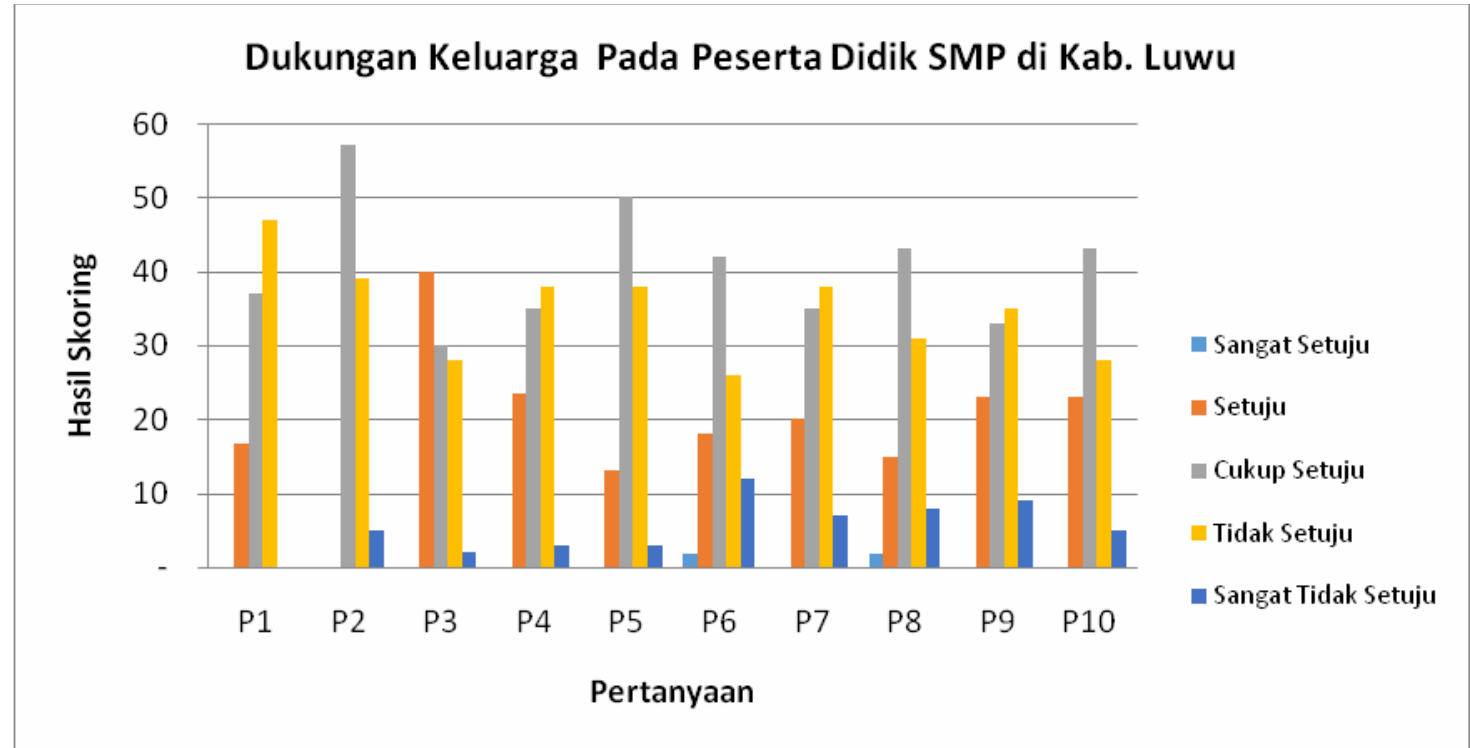

Gambar 2. Grafik Deksriptif Data Dukungan Keluarga

Berikut ini hasil distribusi frekuensi dukungan keluarga pada peserta didik SMP di Kabupaten Luwu, disajikan dalam bentuk tabel yaitu:

Tabel 2. Dukungan Keluarga pada Peserta Didik SMP di Kabupaten Luwu Tahun 2019

\begin{tabular}{lcr}
\hline \multicolumn{1}{c}{$\begin{array}{c}\text { Variabel } \\
\text { Dukungan Keluarga }\end{array}$} & $\begin{array}{c}\text { Frekuensi } \\
\text { (F) }\end{array}$ & \multicolumn{2}{c}{$\begin{array}{c}\text { Persen } \\
\mathbf{( \% )}\end{array}$} \\
\hline Mendukung & 45 & 75,0 \\
Kurang Mendukung & 15 & 25,0 \\
\hline \multicolumn{1}{c}{ Jumlah } & $\mathbf{6 0}$ & $\mathbf{1 0 0 . 0}$ \\
\hline
\end{tabular}

Sumber : Data Primer, 2019

Berdasarkan tabel 2 tentang dukungan keluarga pada peserta didik SMP di Kabupaten Luwu menyatakan bahwa dari 60 responden, sebanyak 45 orang atau 75,0\% yang 
mendapatkan dukungan keluarga, dan sebanyak 15 orang atau 25,0\% yang kurang mendapatkan dukungan keluarga.

\section{Peer Group Support atau Dukungan Teman Sebaya}

Pada bagian ini akan dipaparkan dan dijelaskan temuan data mengenai dukungan teman sebaya, dengan item pertanyaan sebagai berikut:

Tabel 3. Hasil Skoring Item Dukungan Teman Sebaya

\begin{tabular}{|c|l|c|c|c|c|c|c|}
\hline \multirow{2}{*}{ No } & \multicolumn{1}{|c|}{ Pernyataan } & \multicolumn{3}{c|}{ Hasil Skoring (\%) } & Total \\
\cline { 3 - 7 } & & SS & S & CS & TS & STS & \\
\hline 1 & $\begin{array}{l}\text { Bagi saya lingkungan teman sebaya } \\
\text { adalah tempat yang baik untuk saya. }\end{array}$ & 0 & 16,7 & 36,7 & 46,6 & 0,0 & 100,0 \\
\hline 2 & $\begin{array}{l}\text { Saya merasa nyaman dan siap dalam } \\
\text { belajar apabila mempunyai teman } \\
\text { sebaya dalam sekolah yang sama. }\end{array}$ & 1,7 & 38,3 & 55,0 & 5,0 & 0,0 & 100,0 \\
\hline 3 & $\begin{array}{l}\text { Saya merasa tidak enak pada anggota } \\
\text { kelompok teman sebaya lain apabila } \\
\text { saya memilih seklah yang berbeda. }\end{array}$ & 3,3 & 33,3 & 30,0 & 33,4 & 0,0 & 100,0 \\
\hline 4 & $\begin{array}{l}\text { Kelompok teman sebaya saya } \\
\text { mendiskusikan sekolah mana yang } \\
\text { baik bagi kelompok saya. }\end{array}$ & 5,0 & 40,0 & 33,3 & 31,7 & 0,0 & 100,0 \\
\hline 5 & $\begin{array}{l}\text { Teman sebaya memberikan pendapat } \\
\text { untuk saya mengenai sekolah yang } \\
\text { tepat untuk saya. }\end{array}$ & 5,0 & 33,3 & 48,3 & 13,3 & 0,0 & 100,0 \\
\hline 6 & $\begin{array}{l}\text { Bagi saya saran dari teman adalah } \\
\text { yang terbaik. }\end{array}$ & 11,7 & 31,7 & 38,3 & 18,3 & 0,0 & 100,0 \\
\hline 7 & $\begin{array}{l}\text { Informasi yang saya peroleh } \\
\text { mengenai sekolah dari teman sebaya }\end{array}$ & 8,3 & 38,3 & 35,0 & 18,4 & 0,0 & 100,0 \\
\hline 8 & $\begin{array}{l}\text { Saya terbiasa belajar dengan teman } \\
\text { sebaya. }\end{array}$ & 10,0 & 35,0 & 40,0 & 13,3 & 1,7 & 100,0 \\
\hline 9 & $\begin{array}{l}\text { Teman sebaya dapat memberikan } \\
\text { semangat belajar dan motivasi } \\
\text { berprestasi di sekolah }\end{array}$ & 13,3 & 38,3 & 26,7 & 21,7 & 0,0 & 100,0 \\
\hline $\begin{array}{l}\text { Bagi saya lingkungan teman sebaya } \\
\text { adalah tempat yang baik untuk saya. }\end{array}$ & 8,3 & 28,3 & 41,7 & 21,7 & 0,0 & 100,0 \\
\hline
\end{tabular}

Berdasarkan tabel 3 hasil skoring secara keseluruhan pada item dukungan teman sebaya, tabel diatas menunjukkan bahwa sebagian besar keluarga cukup setuju dan sejutu dalam memberikan dukungan terhadap peserta didik SMP di Kabupaten Luwu. Berikut hasil scoring, disajikan dalam bentuk diagram batang: 


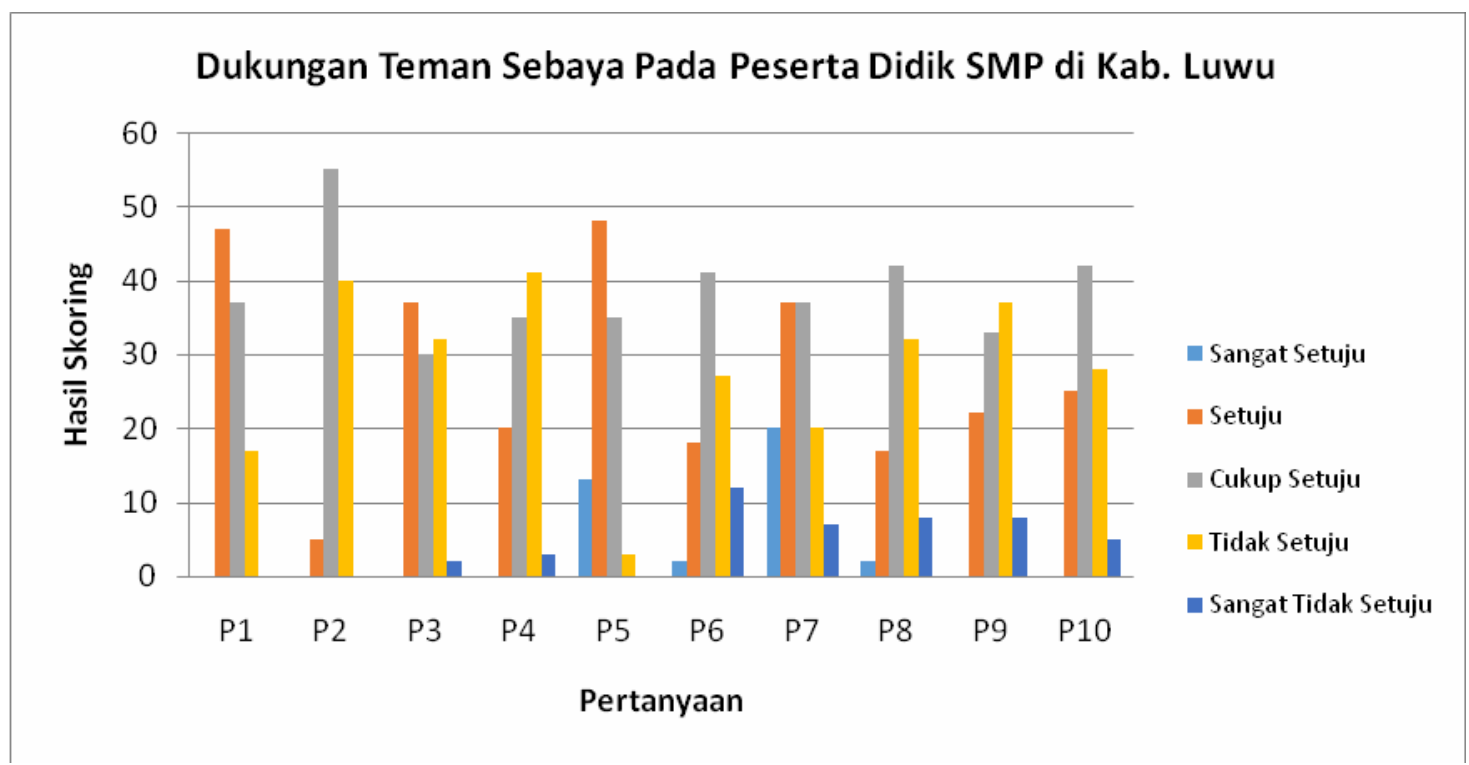

Gambar 2. Grafik Deksripsi Data Dukungan Teman Sebaya

Berikut ini hasil distribusi frekuensi dukungan keluarga pada peserta didik SMP di Kabupaten Luwu, disajikan dalam bentuk tabel yaitu:

Tabel 4. Dukungan Teman Sebaya pada Peserta Didik SMP di Kabupaten Luwu Tahun 2019

\begin{tabular}{lcr}
\hline \multicolumn{1}{c}{$\begin{array}{c}\text { Variabel Dukungan } \\
\text { Teman Sebaya }\end{array}$} & Frekuensi (F) & Persen (\%) \\
\hline Mendukung & 39 & 65,0 \\
Kurang Mendukung & 21 & 35,0 \\
\hline \multicolumn{1}{c}{ Jumlah } & $\mathbf{6 0}$ & $\mathbf{1 0 0 . 0}$ \\
\hline
\end{tabular}

Berdasarkan tabel 4 tentang dukungan teman sebaya pada peserta didik SMP di Kabupaten Luwu menyatakan bahwa dari 60 responden, sebanyak 39 orang atau $65,0 \%$ yang mendapatkan dukungan teman sebaya, dan sebanyak 21 orang atau 35,0\% yang kurang mendapatkan dukungan teman sebaya.

\section{Pemilihan Sekolah Menengah Atas}

Pada bagian ini akan dipaparkan dan dijelaskan temuan data mengenai pemilihan Sekolah Menengah Atas, dengan item pertanyaan sebagai berikut:

Tabel 5. Hasil Skoring Item Pemilihan Sekolah Menengah Atas

\begin{tabular}{|l|l|l|l|}
\hline & Hasil Skoring (\%) & Total \\
\hline
\end{tabular}




\begin{tabular}{|c|c|c|c|c|c|c|c|}
\hline No & Pernyataan & SS & $S$ & CS & TS & STS & \\
\hline 1 & $\begin{array}{l}\text { Saya mencari sekolah lanjutan yang } \\
\text { dapat mengembangkan bakat/minat } \\
\text { saya }\end{array}$ & 0,0 & 46,6 & 36,7 & 16,7 & 0,0 & 100,0 \\
\hline 2 & $\begin{array}{l}\text { Dalam memilih sekolah lanjutan, saya } \\
\text { mempertimbangkan kelebihan dan } \\
\text { kekurangan saya }\end{array}$ & 0,0 & 5,0 & 55,0 & 40,0 & 0,0 & 100,0 \\
\hline 3 & $\begin{array}{l}\text { Untuk melanjutkan sekolah, saya } \\
\text { memilih lebih dari satu alternatif }\end{array}$ & 0,0 & 36,6 & 30,0 & 31,7 & 1,7 & 100,0 \\
\hline 4 & $\begin{array}{l}\text { Saya memilih sekolah lanjutan untuk } \\
\text { mengembangkan keterampilan yang } \\
\text { saya miliki }\end{array}$ & 0,0 & 20,0 & 35,0 & 41,7 & 3,3 & 100,0 \\
\hline 5 & $\begin{array}{l}\text { Saya mempertimbangkan faktor } \\
\text { ekonomi dalam pemilihan sekolah } \\
\text { lanjutan }\end{array}$ & 13,3 & 48,3 & 35,0 & 3,3 & 0,0 & 100,0 \\
\hline 6 & $\begin{array}{l}\text { Saya mencari informasi tentang } \\
\text { kondisi sekolah lanjutan yang saya } \\
\text { pilih }\end{array}$ & 1,7 & 18,3 & 41,7 & 26,6 & 11,7 & 100,0 \\
\hline 7 & $\begin{array}{l}\text { Saya mempertimbangkan kondisi } \\
\text { pergaulan sekolah lanjutan yang akan } \\
\text { saya pilih }\end{array}$ & 20,0 & 36,7 & 36,7 & 20,0 & 6,6 & 100,0 \\
\hline 8 & $\begin{array}{l}\text { Saya mempertimbangkan kondisi } \\
\text { keamanan sekolah lanjutan yang akan } \\
\text { saya pilih }\end{array}$ & 1,7 & 16,7 & 41,7 & 31,7 & 8,3 & 100,0 \\
\hline 9 & $\begin{array}{l}\text { Saya menggali informasi mengenai } \\
\text { pilihan sekolah lanjutan yang saya } \\
\text { inginkan dengan guru yang } \\
\text { berkompeten }\end{array}$ & 0,0 & 21,7 & 33,3 & 36,7 & 8,3 & 100,0 \\
\hline 10 & $\begin{array}{l}\text { Saya mencari sekolah lanjutan yang } \\
\text { dapat mengembangkan bakat/minat } \\
\text { saya }\end{array}$ & 0,0 & 25,0 & 41,7 & 28,3 & 5,0 & 100,0 \\
\hline
\end{tabular}

Berdasarkan tabel 5 hasil skoring secara keseluruhan pada item pemilihan Sekolah Menengah Atas, tabel diatas menunjukkan bahwa sebagian besar peserta didik cukup setuju dan sejutu dalam memilih Sekolah Menengah Atas sesuai dengan bakat/minatnya Kabupaten Luwu. Berikut hasil scoring, disajikan dalam bentuk diagram batang: 


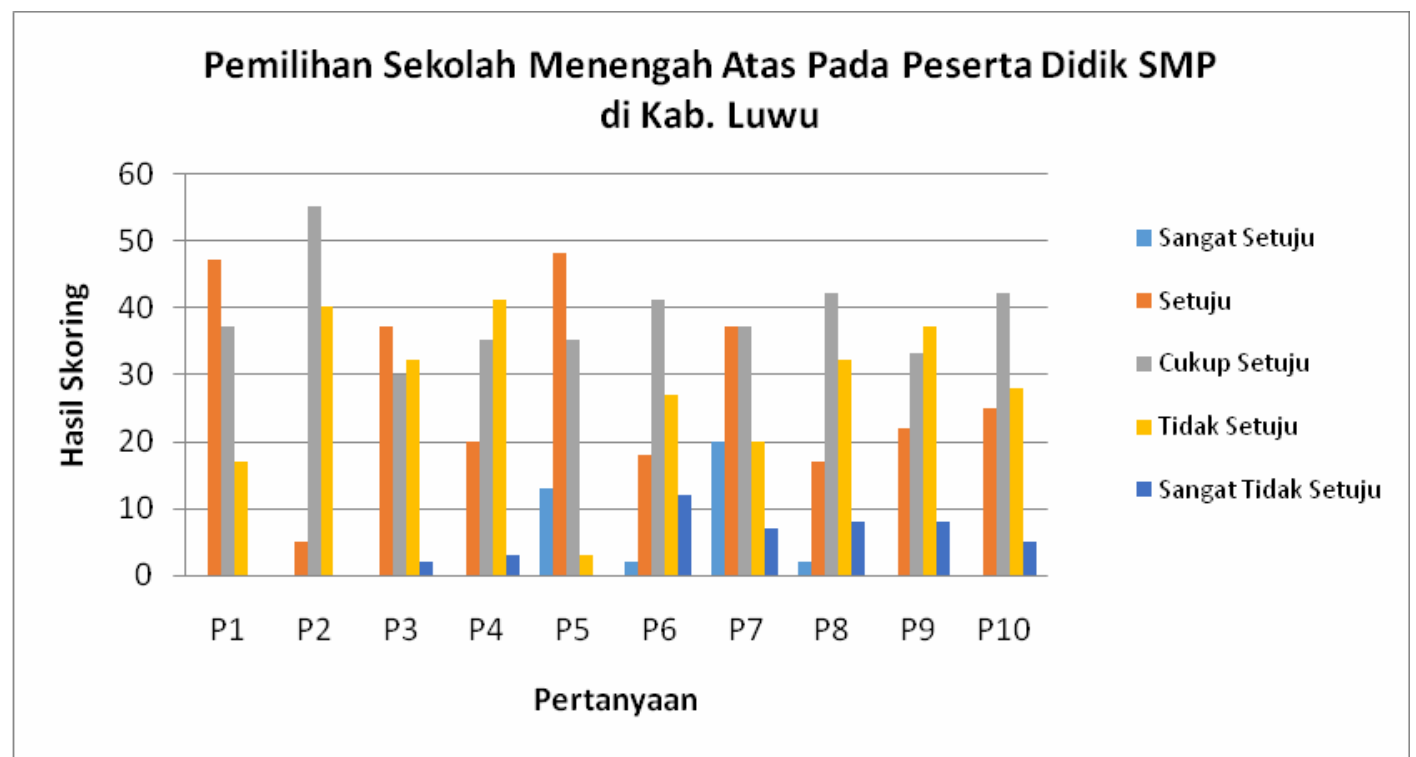

Gambar 3. Grafik Deskripsi Data Pemilihan Sekolah Menengah Atas

Berikut ini hasil distribusi frekuensi pemilihan Sekolah Menengah Atas pada peserta didik SMP di Kabupaten Luwu, disajikan dalam bentuk tabel yaitu:

Tabel 6. Pemilihan Sekolah Menengah Atas pada Peserta Didik SMP di Kabupaten Luwu Tahun 2019

Variabel

Pemilihan Sekolah Menengah

Atas

\begin{tabular}{llc}
\hline Sesuai Bakat/Minat & 44 & 73,3 \\
Tidak Sesuai Bakat/Minat & 16 & 26,7 \\
\hline \multicolumn{1}{c}{ Jumlah } & $\mathbf{6 0}$ & $\mathbf{1 0 0 . 0}$ \\
\hline
\end{tabular}

\section{Frekuensi (F) \\ Persen (\%)}

Berdasarkan tabel 6 tentang dukungan teman sebaya pada peserta didik SMP di Kabupaten Luwu menyatakan bahwa dari 60 responden, sebanyak 39 orang atau $65,0 \%$ yang mendapatkan dukungan teman sebaya, dan sebanyak 21 orang atau 35,0\% yang kurang mendapatkan dukungan teman sebaya.

\section{Hubungan dukungan keluarga terhadap pemilihan Sekolah Menengah Atas dan Sederajat pada Peserta Didik SMP di Kabupaten Luwu.}

Di dalam melakukan analisis, peneliti menggunakan teknik analisis korelasi dengan metode Korelasi koefisien Kontingensi. Uji ini mengetahui tingkat keeratan/kekuatan hubungan antar variabel. Karena dalam penelitian sebelumnya telah dilihat arah hipotesanya adalah kolerasi. Berikut hubungan 
antar variabel yaitu :

Tabel 7. Kolerasi dukungan keluarga terhadap pemilihan Sekolah Menengah Atas dan Sederajat pada Peserta Didik SMP di Kabupaten Luwu

\begin{tabular}{|c|c|c|c|c|c|c|c|c|}
\hline \multirow{3}{*}{ Dukungan Keluarga } & \multicolumn{4}{|c|}{ Pemilihan SMA } & & & \multirow{3}{*}{$\begin{array}{c}\text { Koefisien } \\
\text { Kolerasi } \\
\text { (r) }\end{array}$} & \multirow{3}{*}{$\begin{array}{c}\text { Nilai } \\
\rho\end{array}$} \\
\hline & \multicolumn{2}{|c|}{$\begin{array}{c}\text { Sesuai } \\
\text { Bakat/Minat }\end{array}$} & \multicolumn{2}{|c|}{$\begin{array}{l}\text { Tidak Sesuai } \\
\text { Bakat/Minat }\end{array}$} & \multicolumn{2}{|c|}{ Jumlah } & & \\
\hline & $\mathbf{f}$ & $\%$ & $\mathbf{f}$ & $\%$ & $\mathbf{F}$ & $\%$ & & \\
\hline Mendukung & 43 & 71,6 & 2 & 3,4 & 45 & 75 & & \\
\hline Kurang Mendukung & 1 & 1,7 & 14 & 23,3 & 15 & 25 & 657 & ,000 \\
\hline Total & 44 & 73,3 & 16 & 26,7 & 60 & 100 & & \\
\hline
\end{tabular}

\section{Uji kolerasi koefisien kontingensi}

Berdasarkan tabel diatas menunjukkan bahwa dari 60 jumlah responden secara keseluruhan, yang mendapatkan dukungan keluarga terhadap pemilihan SMA dan Sederajat sesuai dengan bakat/minat peserta didik SMP sebanyak 43 orang atau $71,6 \%$, dan yang mendapatkan dukungan keluarga terhadap pemilihan SMA dan Sederajat tidak sesuai dengan bakat/minat peserta didik SMP sebanyak 2 orang atau 3,4\%. Sedangkan yang kurang mendapatkan dukungan keluarga terhadap pemilihan SMA dan Sederajat sesuai dengan bakat/minat peserta didik SMP sebanyak 1 orang atau 1,7\%, dan yang kurang mendapatkan dukungan keluarga terhadap pemilihan SMA dan Sederajat tidak sesuai dengan bakat/minat peserta didik SMP sebanyak 14 orang atau 23,3\%.

Berdasarkan uji kolerasi koefisien kontingensi diperoleh nilai $\rho=, 000$, yang menunjukkan bahwa kolerasi antara dukungan keluarga terhadap pemilihan SMA atau sederajat bermakna secara statistik. Nilai kolerasi sebesar ,657 menunjukkan kolerasi positif dengan kekuatan kolerasi yang kuat. Hal tesebut berarti bahwa semakin baik dukungan keluarga terhadap peserta didik maka semakin baik pula peserta didik dalam melakukan pemilihan SMA atau sederajat.

Hubungan Peer Group Support atau Dukungan Teman Sebaya terhadap pemilihan Sekolah Menengah Atas dan Sederajat pada Peserta Didik SMP di Kabupaten Luwu.

Di dalam melakukan analisis, peneliti menggunakan teknik analisis korelasi dengan metode Korelasi koefisien Kontingensi. Uji ini mengetahui tingkat keeratan/kekuatan hubungan antar variabel. Karena dalam penelitian sebelumnya telah dilihat arah hipotesanya adalah kolerasi. Berikut hubungan 
antar variabel yaitu :

Tabel 4.7 Kolerasi dukungan teman sebaya terhadap pemilihan Sekolah Menengah Atas dan Sederajat pada Peserta Didik SMP di Kabupaten Luwu

\begin{tabular}{|c|c|c|c|c|c|c|c|c|}
\hline \multirow{3}{*}{$\begin{array}{c}\text { Dukungan Teman } \\
\text { Sebaya }\end{array}$} & \multicolumn{4}{|c|}{ Pemilihan SMA } & & \multirow[b]{2}{*}{ nlah } & \multirow{3}{*}{$\begin{array}{c}\text { Koefisien } \\
\text { Kolerasi } \\
\text { (r) }\end{array}$} & \multirow{3}{*}{$\begin{array}{c}\text { Nilai } \\
\rho\end{array}$} \\
\hline & \multicolumn{2}{|c|}{$\begin{array}{c}\text { Sesuai } \\
\text { Bakat/Minat }\end{array}$} & \multicolumn{2}{|c|}{$\begin{array}{l}\text { Tidak Sesuai } \\
\text { Bakat/Minat }\end{array}$} & Jü & & & \\
\hline & f & $\%$ & $\mathbf{f}$ & $\%$ & $\mathbf{F}$ & $\%$ & & \\
\hline Mendukung & 37 & 61,6 & 2 & 3,4 & 39 & 65 & & \\
\hline Kurang Mendukung & 7 & 11,7 & 14 & 23,3 & 21 & 35 & ,553 & ,000 \\
\hline Total & 44 & 73,3 & 16 & 26,7 & 60 & 100 & & \\
\hline
\end{tabular}

Uji kolerasi koefisien kontingensi

Berdasarkan tabel diatas menunjukkan bahwa dari 60 jumlah responden secara keseluruhan, yang mendapatkan dukungan teman sebaya terhadap pemilihan SMA dan Sederajat sesuai dengan bakat/minat peserta didik SMP sebanyak 37 orang atau $61,6 \%$, dan yang mendapatkan dukungan teman sebaya terhadap pemilihan SMA dan Sederajat tidak sesuai dengan bakat/minat peserta didik SMP sebanyak 2 orang atau 3,4\%. Sedangkan yang kurang mendapatkan dukungan teman sebaya terhadap pemilihan SMA dan Sederajat sesuai dengan bakat/minat peserta didik SMP sebanyak 7 orang atau 11,7\%, dan yang kurang mendapatkan dukungan teman sebaya terhadap pemilihan SMA dan Sederajat tidak sesuai dengan bakat/minat peserta didik SMP sebanyak 14 orang atau $23,3 \%$.

Berdasarkan uji kolerasi koefisien kontingensi diperoleh nilai $\rho=, 000$, yang menunjukkan bahwa kolerasi antara dukungan teman sebaya terhadap pemilihan SMA atau sederajat bermakna secara statistik. Nilai kolerasi sebesar ,553 menunjukkan kolerasi positif dengan kekuatan kolerasi yang sedang. Hal tesebut berarti bahwa semakin baik dukungan teman sebaya terhadap peserta didik maka semakin baik pula peserta didik dalam melakukan pemilihan SMA atau sederajat.

\section{KESIMPULAN}

Berdasarkan kajian yang telah dilakukan selama penelitian maka dapat disimpulkan bahwa adanya kontribusi positif layanan penguasaan konten (PKO) dalam meningkatkan sikap empati siswa dan perubahan sikap empati siswa atas kontribusi layanan penguasaan konten (PKO) terjadi secara signifikan. 


\section{DAFTAR PUSTAKA}

Bernal, A., Urpí, C., Sonia , S., \& R., R. (2011). Social Values and Authority in Education: Collaboration between School and Families. Aurora Bernal, Carmen Urpí, Sonia Rivas, Rosario Repáraz, Social Values and Authority in EducInternational Journal about Parents in Education, 134.

Bursal, M. (2017). Academic Achievement and Perceived Peer Support among Turkish Students: Gender and Preschool Education Impact. Murat BURSAL, Academic Achievement and Perceived Peer Support among Turkish Students:International Electronic Journal of Elementary Education, 599-612.

Chairunnissa, A. S. (2010). Hubungan Antara Penerimaan Kelompok Teman Sebaya dengan Prestasi Akademik Mahasiswa Pada Fakultas Ekonomi Universitas Negeri Jakarta. Ati Sumiati Chairunnissa, Hubungan Antara Penerimaan Kelompok Teman Sebaya Dengan Prestasi Akademik Mahasiswa Pada Fakul Jurnal Ekonomi \& Pendidikan, 107.

Desmita. (2009). Psikologi perkembangan. Bandung: Remaja Rosdakarya.

Dharmayanti, W. (2014). Faktor-faktor Yang Memengaruhi Minat Siswa SMP Masuk SMK di Kota Pontianak. Jurnal Pendidikan Vokasi, 406.

Ghozaly, L. F. (2011). Pengaruh Kelompok Teman Sebaya dan Media Massa Terhadap Keterampilan Sosial Atlet Muda di SMA Negeri Ragunan Jakarta. Bogor: Institut Pertanian Bogor.

Hidajat, M. (2015). Dampak Media Sosial Dalam Cyber Bullying. ComTech, 80.

Lestari, S. (2012). Psikologi Keluarga: Penanaman Nilai dan Penanganan Konflik Dalam Keluarga. Jakarta: Kencana Prenada Media Group.

Maryati, S. (2009). Faktor-faktor yang Mempengaruhi Preferensi Masyarakat dalam Memilih Sekolah Menengah Kejuruan Negeri (SMKN) di Kota Semarang. Semarang: Universitas Diponegoro.

Ritzer, G., \& Goodman, D. J. (2012). Teori Sosiologi Modern. Jakarta: Kenanga.

Rochnaningsih, N. S. (2014). Dampak Pergeseran Peran dan Fungsi Keluarga Pada Perilaku Menyimpang Remaja. Jurnal Pembangunan Pendidikan: Fondasi dan Aplikasi, 61.

Santrock, J. (2007). Perkembangan anak. Jakarta: Erlangga.

Steinberg. (2001). Adolescence. New York: Mc Graw Hill Higher Education. 
Sung, M., \& Park, J. (2012). The effects of a family support program including respite care on parenting stress and family quality of life perceived by primary caregivers of childeren with disabilities in korea. International Journal Of Special Education, 188.

Trisnawarman, D., \& Livereja, M. (2006). Aplikasi sistem pendukung keputusan pemilihan sekolah. Jakarta: SNATI.

Undang-Undang Republik Indonesia Nomor 20 Tahun 2003 Tentang Sistem Pendidikan Nasional pasal 3. (2003). Jakarta: Presiden Republik Indonesia. 